\title{
An Indirect Impact of the Price to Book Value to the Stock Returns: An Empirical Evidence from the Property Companies in Indonesia
}

\author{
M. Shabri Abd. Majid ${ }^{1 *}$ and Benazir ${ }^{1}$ \\ Faculty of Economics and Business, \\ Syiah Kuala University, Darussalam, Banda Aceh, Indonesia \\ *Corresponding Author: mshabri@unsyiah.ac.id
}

\begin{abstract}
This research empirically examines the influence of Dividend Payout Ratio (DPR), Return on Equity (ROE), Growth, and Degree of Financial Leverage (DFL) on the Price to Book Value (PBV) of the property companies in Indonesia. It also attempts to explore the indirect effects of the DPR, ROE, Growth, and DFL on the stock returns via the PBV. 36 property firms, which are listed in the Indonesian Stock Exchange from 2007 to 2013, were selected to be analyzed using the Path Analysis. The result of this research indicates that the variable of growth is found to have a significant impact on PBV. Meanwhile, the DPR, ROE, and DFL were found to be insignificant. The DPR, ROE, Growth, and DFL were found to affect PBV simultaneously. This study also proved that the PBV has a significant effect on the stock returns, while the DPR and DFL were not. The study also found that the DPR, PBV, and DFL have simultaneously affected stock returns of the property companies in Indonesia. The finding of this study implied that to predict the stock returns of the property companies, the investors and companies should take into account the changes in the growth and PBV.
\end{abstract}

Keywords: Dividend payout ratio; return on equity; growth; degree of financial leverage; price to book value; stock returns.

\begin{abstract}
ABSTRAK
Penelitian ini menguji pengaruh Dividend Payout Ratio (DPR), Return on Equity (ROE), Growth, dan Degree of Financial Leverage (DFL) pada Price to Book Value (PBV) pada perusahaan properti di Indonesia. Penelitian ini juga memeriksa pengaruh tidak langsung dari DPR, ROE, growth, dan DFL pada Stock Returns melalui PBV. Penelitian ini menggunakan 36 perusahaan properti pada tahun 2007-2013 yang terdaftar di Bursa Efek Indonesia untuk dianalisis menggunakan Path Analysis. Hasil penelitian ini menunjukkan bahwa variabel growth memiliki pengaruh yang signifikan terhadap PBV, sementara itu tidak ditemukan demikian pada variabel DPR, ROE, dan DFL. Variabel DPR, ROE, Growth, dan DFL ditemukan mempengaruhi PBV secara simultan. Penelitian ini juga membuktikan bahwa PBV memiliki pengaruh signifikan pada stock returns, sedangkan DPR dan DFL tidak. Penelitian ini juga menemukan bahwa DPR, PBV, dan DFL mempengaruhi stock return secara simultan mempengaruhi perusahaan properti di Indonesia. Penelitian ini menunjukkan bahwa investor dan perusahaan harus memperhitungkan perubahan dalam growth dan PBV untuk memprediksi stock returns perusahaan properti Indonesia.
\end{abstract}

Kata kunci: Dividend payout ratio; return on equity; growth; degree of financial leverage; price to book value; stock returns.

\section{INTRODUCTION}

Currently, Indonesia's economy continues to improve providing a conducive environment for investors to invest their money in the financial market. The capital market is one of the financial markets, which provide complete and updated information on stock market from time to time. 
The development of capital markets and securities industry have attracted investors to limit their funds to be deposited in the banks and other savings instruments, but invested more in the capital market, particularly in the stocks (Husnan, 2005).

Stock is one of the financial assets which are traded in the stock market, can be defined as a sign of firm ownership or possession of a shareholder in the form of a sheet of paper that explains who the owner is. Investors buy shares in a company with the hope of gaining future return. Therefore, investments made in stocks of productive enterprise, the business object has a perspective and avoid the falling value of the stock due to the economic cyclical impact as an investment risk that is often threatening. In determining the shares to be purchased, we must judge in advance to avoid speculation and unexpected loss, because the stock price fluctuates from time to time. Therefore, investors have to predict how much the rate of return they will earn on their investment by way of measuring the value of the share price.

According to Hartono (2000:79), there are three types of assessment related to the shares, i.e., the book value, market value, and the intrinsic value. Investors need to know and understand these values as important information for decision making in stock investments, because it helps investors to find out which stocks are growing and inexpensive. One approach in determining the intrinsic value of stocks is Price to Book Value (PBV). PBV shows the relationship between stock market price and book value per share (Jones, 2000: 274). Investors can consider the ratio of capital markets such as PBV ratio to distinguish where the stock price is reasonable, too high (overvalued), or too low (undervalued). This strategy is generally connected the PBV ratio with the intrinsic value of shares which is estimated based on the stock assessment model, using the potential factors affecting the PBV such as Dividend Payout Ratio, Return On Equity, Growth and Degree of Financial Leverage. Rosenberg et al. (1985) found that stocks with low PBV ratio would produce returns that are significantly higher compared to stocks that have a high PBV ratio. Utama and Santoso (1998) also found that the PBV had a negative relationship with stock returns. While Fama and French (1992) showed that, the ratio of book value to market value may explain the differences in better results than beta, and consider the ratio of book value to market as a good proxy for the fundamental variable. Vaidyanathan and Sudheer (1997) found that the shares with a lower Price to Book Value would yield a higher return than the stock that has a high Price to Book Value.
Based on the above research background, this study empirically examines the influence of Dividend Payout Ratio (DPR), Return on Equity (ROE), Growth, and Degree of Financial Leverage (DFL) on the Price to Book Value (PBV) of the property companies in Indonesia. It also attempts to explore the indirect effects of the DPR, ROE, Growth, and DFL on the stock returns via the PBV. 36 property firms, which are listed in the Indonesian Stock Exchange from 2007 to 2013, were selected to be analyzed using the Path Analysis. Path analysis is a technique uses to analyze the relationships among the endogenous and exogenous variables either directly or indirectly (Robert, 2007).

The findings of this study is hoped to shed some lights to the investors in valuing and selecting stocks; to policy makers in regulating stock markets, and to the companies to provide an attractive returns and maximize the welfare of its shareholders.

The rest of the study is organized as follows. Section 2 highlights the empirical framework and data preliminaries of the study. Section 3 discusses the empirical findings. Finally, section 4 summarises the major findings and draws some relevant policy implications and suggestion for future research.

\section{RESEARCH METHODS}

\section{Data and Sample Research}

This study uses secondary data of financial statements of 36 property companies listed in the Indonesian stock exchange, including balance sheet, income statement, the stock price data, the book value of equity, dividends per share, earnings per share, stock return and other data relevant to this study during the years 2007-2013, accessed from www.idx.co.id, www.Sahamok.com and www.duniainvestasi.com.

\section{Operational variables}

Operational variables are provided to limit the variables used in the study. The variables are operationalized in this study consists of:

\section{Stock returns}

Stock return is the rate of return on stock investments made (Tandelilin, 2001). The concept of return divided by Jogiyanto (2003) into two, namely: a single return and portfolio return. Single return is the result obtained in the form of return of investment, realized return and expected return. The realize return is a return that has happened, 
which is calculated based on historical data. Realize return is used as one of tools to assess the performance of company. These historical returns are also useful as a basis for determining the expected return and future risk. While the portfolio returns is a weighted average of the return of each stock. Stock returns can be calculated using the formula:

$$
\mathrm{R} i=\frac{P_{i t}-P_{i t-1}}{P_{i t-1}}
$$

Where:

Ri: Stock return i

$\mathrm{P}_{\mathrm{it}}$ : closing stock price i on this stage

$\mathrm{P}_{\mathrm{it}-1}$ : the closing stock price $\mathrm{i}$ on the previous period.

Price to book value

Price to Book Value (PBV) is a ratio used to measure market price performance to the book value of stock market. PBV ratio is the ratio between stock prices and book value of equity (Ang, 1997). The PBV is calculated as:

$$
\mathrm{PBV}=\frac{\text { Share Price }}{\text { Book Value }}
$$

Dividend payout ratio

Dividend Payout Ratio (DPR) is the percenttage of profits distributed as dividends. This ratio is the policy of dividends paid to investors. Dividend payout ratio obtained by dividing the dividend per share by earnings per share (Wirawati, 2008). The DPR is calculated as:

$$
\mathrm{DPR}=\frac{\text { Dividend }}{E A T}
$$

\section{$\underline{\text { Return on Equity }}$}

Return on Equity (ROE) is the ratio of profit after tax to equity capital. This ratio measures the company's ability to generate profit on own capital (Husnan, 2005). The formula of ROE is:

$$
\mathrm{ROE}=\frac{\text { Net Profit }}{\text { Total Equity }}
$$

\section{The rate of growth}

The rate of growth is calculated as an average growth rate of ROE (Wirawati, 2008; Wardjono 2010), with the following formula:

$$
\text { Growth }=\frac{R O E_{t}-\mathrm{ROE}_{\mathrm{t}-1}}{R O E_{t-1}}
$$

\section{$\underline{\text { Degree of financial leverage }}$}

Degree of financial leverage (DFL) is used to find out how much the percentage changes in earnings per share (EPS) caused by changes in EBIT (Earnings before Interest and Tax). The greater the value of the DFL, the greater financial risk because the company's corporate debt is also large (Wirawati, 2008). DFL is calculated as:

$$
\mathrm{DFL}=\frac{\% \Delta E P S}{\% \Delta E B I T}
$$

\section{Data Analysis Tools}

The path analysis is adopted in this study to empirically explore: (i) direct influences of the DPR, ROE, Growth and DFL on the PBV; (ii) direct influences of the DPR, ROE, Growth and DFL on the stock returns; and (iii) indirect impacts of the DPR, ROE, Growth and DFL on the returns via PBV. Diagram 1 is the path analysis model, showing the influences of exogenous variables on endogenous variables both directly and indirectly.

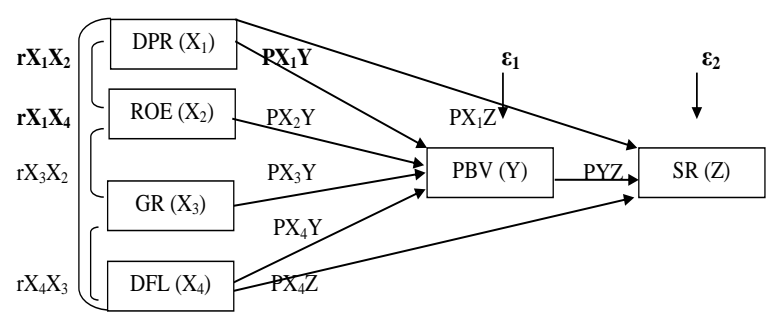

Diagram 1. Path Analysis Model

The above path analysis model can be rewritten in the following structural equations (models):

Model 1: $\mathrm{Y}=\mathrm{PX}_{1} \mathrm{Y}+\mathrm{PX}_{2} \mathrm{Y}+\mathrm{PX}_{3} \mathrm{Y}+\mathrm{PX}_{4} \mathrm{Y}+\varepsilon_{1}$

Model 2: $\mathrm{Z}=\mathrm{PX}_{1} \mathrm{Z}+\mathrm{PYZ}+\mathrm{PX}_{4} \mathrm{Z}+\varepsilon_{2}$

Where $\mathrm{X}_{1}$ is the Dividend Payout Ratio (DPR), $\mathrm{X}_{2}$ is the Return on Equity (ROE), $\mathrm{X}_{3}$ is the

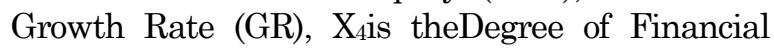
Leverage (DFL), $\mathrm{Y}$ is the Price to Book Value (PBR), $\mathrm{Z}$ is the Stock Returns (SR), $\varepsilon_{1}$, $\varepsilon_{2}$ are the Error Terms, $\mathrm{PX}_{1}$ Yis the Path coefficient of a direct effect of $\mathrm{X}_{1}$ on $\mathrm{Y}, \mathrm{PX}_{2} \mathrm{Y}$ is the Path coefficient of a direct effect of $\mathrm{X}_{2}$ on $\mathrm{Y}, \mathrm{PX}_{3} \mathrm{Yis}$ the Path coefficient of a direct effect of $\mathrm{X}_{3}$ on $\mathrm{Y}, \mathrm{PX}_{4} \mathrm{Yis}$ the Path coefficient of a direct effect of $\mathrm{X}_{4}$ on $\mathrm{Y}, \mathrm{PX}_{1} \mathrm{Z}$ is the Path coefficient of a direct effect of $\mathrm{X}_{1}$ on $\mathrm{Z}$, PYZis the Path coefficient of a direct effect of $Y$ on $Z$, and $\mathrm{PX}_{4} \mathrm{Z}$ is the Path coefficient of a direct effect of $\mathrm{X}_{4}$ on Z. 


\section{RESULTS AND DISCUSSION}

Table 1. Results of Pearson Correlation

\begin{tabular}{lrrrrrr}
\hline Variable & \multicolumn{1}{c}{ SR } & PBV & DPR & ROE & GR & DFL \\
\hline SR & 1.000 & & & & & \\
PBV & $-0.581^{* *}$ & 1.000 & & & & \\
DPR & 0.275 & -0.145 & 1.000 & & & \\
ROE & 0.053 & -0.026 & $-0.378^{*}$ & 1.000 & & \\
GR & -0.078 & $0.497^{* *}$ & -0.034 & 0.121 & 1.000 & \\
DFL & -0.075 & 0.107 & 0.021 & $-0.398^{*}$ & $0.391^{*}$ & 1.000 \\
\hline
\end{tabular}

Note: * and ** indicate significance at the $1 \%$ and $5 \%$ levels

Based on Table 1 , only variable PBV with SR, ROE with DPR, GR with PBV, DFL with ROE, and DFL with GR were found to be significantly correlated with the level of significance of $5 \%$, while other variables were found to be insignificant.

\section{Results of Path Analysis}

The results of the path analysis on the effects of exogenous variables partially on the endogenous variable for Model 1 and Model 2 are reported in Tables 2 and 3, respectively.

Referring to Tables 2, only the GR is found to have a positive and significant effect on PBV. Meanwhile, as reported in Table 3, the PBV only found to have a negative and significant effect on SR. The other investigated exogenous variables were found to be insignificant in affecting either PBV or SR. This implies that the growth rate plays an important role in explaining the PBV, and in turn, the PBV significantly affected SR. These results contrast to the study by Wirawati (2008) which found insignificant effect of ROE on PBV. This could be due to the external factors that occur in parts of the world that spilled over to Indonesia, such as the 2007 global crisis and 2010 debt crisis, which led to difficulties for companies to accumulate profit for their shareholders. However, in line with research conducted by Nainggolan (2008), where ROE has no effect on stock prices, where the share price performance itself is measured by using the PBV, as indicated by the comparison between the stock price to book value. However, these results are consistent with the study of Wardjono (2010) which found that companies with high ratio of DFL would have high risk of its debts and impacted the financial distress (risk bankruptcy) of the companies.

In addition, our results of insignificant effect of DPR ob PBV, confirming the theory of Modiglini and Miller (MM) (Brigham, 1983) which states that a company's value (PBV) is not determined by the size of dividend payments. However, this finding supported the previous study by Wardjono (2010), which found that the DPR affected insignificantly the PBV. As for the finding of negative relation between PBV and SR, it is consintent with the study by Fama and French (1992), Chan et al. (1991). Rosenberg et al. (1985) also found that stocks with low PBV ratio produced returns that are significantly higher compared to stocks that have a high PBV ratio.

Test of coefficients of determination $\left(\mathrm{R}^{2}\right)$ which is reported in Table 4 is conducted to know the extent to which the exogenous variables explain the variation in the endogenous variable.

Table 2. Result of Path Analysis (DPR, ROE, Growth, DFL on PBV)

\begin{tabular}{lccccc}
\hline \multirow{2}{*}{ Variable } & \multicolumn{2}{c}{$\begin{array}{c}\text { Unstandardize } \\
\text { d Coefficients }\end{array}$} & $\begin{array}{c}\text { Stan- } \\
\text { dardized } \\
\text { Coefficients }\end{array}$ & t-value & $\begin{array}{c}\text { Sig. } \\
\text { Level }\end{array}$ \\
\cline { 2 - 6 } & B & $\begin{array}{c}\text { Std. } \\
\text { Error }\end{array}$ & Beta & & \\
\hline Constant & 0.789 & 0.291 & & 2.713 & 0.011 \\
DPR & -0.232 & 0.179 & -0.226 & -1.296 & 0.206 \\
ROE & -0.025 & 0.017 & -0.283 & -1.412 & 0.169 \\
GR & 0.115 & 0.034 & $0.619^{* * *}$ & 3.377 & 0.002 \\
DFL & -8.276 & 6.829 & -0.243 & -1.212 & 0.236 \\
\hline NOte: & & &
\end{tabular}

Note: ${ }^{* * *}$ indicates significance at the $10 \%$ level.

Table 3. Result of Path Analysis (DPR, PBV, DFL on SR)

\begin{tabular}{cccccc}
\hline \multirow{2}{*}{ Variable } & \multicolumn{2}{c}{$\begin{array}{c}\text { Unstandardize } \\
\text { d Coefficients }\end{array}$} & $\begin{array}{c}\text { Stan- } \\
\text { dardized } \\
\text { Coefficients }\end{array}$ & t-value & $\begin{array}{c}\text { Sig. } \\
\text { Level }\end{array}$ \\
\cline { 2 - 6 } & B & $\begin{array}{c}\text { Std. } \\
\text { Error }\end{array}$ & Beta & & \\
\hline Constant & 0.096 & 0.142 & & 0.673 & 0.506 \\
DPR & 0.144 & 0.111 & 0.196 & 10.295 & 0.206 \\
PBV & -0.395 & 0.109 & $-0.551^{* * *}$ & -3.626 & 0.001 \\
DFL & -0.494 & 3.669 & -0.020 & -0.135 & 0.894 \\
\hline Note. ***indicates significance at the $10 \%$ &
\end{tabular}

Table 4. Result of Coefficient of Determination (DPR, PBV, DFL, GR and PBV)

\begin{tabular}{ccccccc}
\hline Model & \multirow{2}{*}{$\mathrm{R}$} & \multirow{2}{*}{$\mathrm{R}^{2}$} & $\begin{array}{c}\text { Adjusted } \\
\mathrm{R}^{2}\end{array}$ & $\begin{array}{c}\text { Std. } \\
\text { Error }\end{array}$ & F-value & $\begin{array}{c}\text { Sig. } \\
\text { Level }\end{array}$ \\
\hline 1 & 0.567 & 0.322 & 0.221 & 0.649 & 3.200 & 0.028 \\
2 & 0.613 & 0.375 & 0.308 & 0.438 & 5.609 & 0.004 \\
\hline
\end{tabular}

Note: Model 1: $\mathrm{Y}=\mathrm{PX}_{1} \mathrm{Y}+\mathrm{PX}_{2} \mathrm{Y}+\mathrm{PX}_{3} \mathrm{Y}+\mathrm{PX}_{4} \mathrm{Y}+\varepsilon_{1}$ Model 2: $\mathrm{Z}=\mathrm{PX} \mathrm{Z}+\mathrm{PYZ}+\mathrm{PX}_{4} \mathrm{Z}+\varepsilon_{2}$

Coefficient of determination $\left(\mathrm{R}^{2}\right)$ in Table 4 for the endogenous variable (PBV) obtained values of coefficient of determination of 0.322 , meaning that $32.2 \%$ of variation in PBV was explained by changes in the DPR, ROE, GR, and DFL, while the rest of $67.8 \%$ was explained by other factors which not explored in this study. In addition, the $37.5 \%$ 
variation in SR was explained by $\mathrm{DPR}, \mathrm{PBV}$ and DFL, while the remaining $62.5 \%$ was explained by other factors, which are not included in this study.

When the simultaneous effects of exogenous variables on endogenous variable are investigated, the study found that the DPR, ROE, Growth, DFL and DPR, PBV, DFL were able to explained the PBV and SR at $5 \%$ and $1 \%$ level of significances, respectively (see Tables 2 and 3).

The results of the path analysis, which are reported in Tables 2 and 3, can be presented in the following equations:

$$
\begin{gathered}
\mathrm{Y}=-0.226 \mathrm{X}_{1}-0.283 \mathrm{X}_{2}-0.619 \mathrm{X}_{3}-1.243 \mathrm{X}_{4}+\varepsilon_{1} \\
\mathrm{Z}=0.196 \mathrm{X}_{1}-0.551 \mathrm{Y}-0.020 \mathrm{X}_{4}+\varepsilon_{2}
\end{gathered}
$$

Table 5 reports the results of direct and indirect effects of exegenous variables on the endegenous variable. The total of direct effects (0.343) is found to be greater than the indirect effects (0.074). this indicated that in predicting the movements of the stock retursn of the property companies in Indonesia, the direct effects of the exegenous variables were more dominant than their indirect effects.

Table 5. Results of Path Analysis: Direct, Indirect and Total Effects

\begin{tabular}{cccc}
\hline Effects of Variables & Direct Effect & Indirect Effect & Total \\
\hline Effect $\mathrm{X}_{1}$ on $\mathrm{C}$ & $0.196 \times 0.196$ & & 0.038 \\
Effect Yon $\mathrm{C}$ & $(-0.551) \times(-0.551)$ & & 0.304 \\
Effect $\mathrm{X}_{4}$ on $\mathrm{Z}$ & $(-0.020) \times(-0.020)$ & & 0.001 \\
\hline \multicolumn{2}{c}{ Total Direct Effect } & & 0.343 \\
\hline Effect $\mathrm{X}_{1}$ on $\mathrm{Z}$ via Y & $(-0.226) \times(-0.551)$ & 0.125 \\
Effect $\mathrm{X}_{2}$ on $\mathrm{Z}$ via Y & $(-0.283) \times(-0.551)$ & 0.156 \\
Effect $\mathrm{X}_{3}$ on $\mathrm{Z}$ via Y & $(0.619) \times(-0.551)$ & -0.341 \\
Effect $\mathrm{X}_{4}$ on $\mathrm{Z}$ via Y & $(-0.243) \times(-0.551)$ & 0.134 \\
\hline \multicolumn{2}{c}{ Total Indirect Effect } & 0.074 \\
\hline \multicolumn{2}{c}{ Total Effects } & 0.417 \\
\hline
\end{tabular}

In addition, the complete results of the path analysis of direct and indirect effects of exogenous variables on the endogenous variables can be portrayed in the Diagram 2, as below.

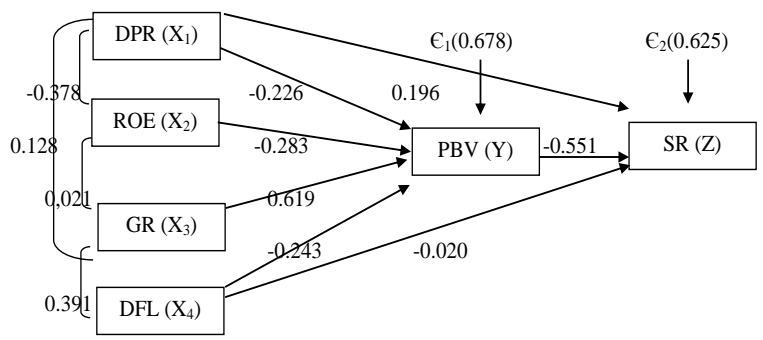

Diagram 2. Factors Affecting the PBV and their Indirect Impacts to SR

\section{CONCLUSIONS}

Based on the above findings and discussion, the following conclusions can be made pertaining to the effects of PBV determinants and their indirect impacts to the stock returns of the property companies in Indonesia:

1. The DPR was found to have an insignificant effect partially on the PBV of the property companies in Indonesia during the period 2007 to 2010.

2. Partially, the GR was found to have a positive and significant direct effect on the PBV of the $\mathrm{PBV}$ of the 36 property companies in Indonesia during the period 2007 to 2010.

3. The DPR, GR, and DFL were found to have a simultaneous and significant effect on the PBV of the 36 property companies in Indonesia during the period 2007 to 2010

4. The study found that $32.2 \%$ of the variation in the PBV was explained by changes in the DPR, ROE. GR, and DFL, while the rest $67.8 \%$ was explained by other variables, which are not investigated in the study. Meanwhile the variation in the SR was explained about $37.5 \%$ by the changes in the DPR, DFL and PBV, while the remaining $62.5 \%$ was explained by other variables outside of this research.

5. The SR also indirect affected by the exogenous variable via the $\mathrm{PBV}$, implying that to predict stock returns the investors should consider both direct and indirect effects of the exogenous variables, particularly the GR on PBV and in turn on the SR.

Based on the above findings, some recommendations and suggestions for future research in this area are provided as follows:

1. For the investors who invest their money in the property sector in Indonesian stock market, they should consider the potential growth of equity of a company with more carefully so that they are able to generate profits as expected.

2. This study only discusses the factors affecting PBV and their indirect effects on the company's stock returns of the property companies in Indonesia. Further research should also take into consideration other potential factors determining the PBV and SR as well as incorporateing more sectors of stocks. It is also suggested that the future study should compare the valuetion of stocks of the companies in Indonesia with their foreign counterpart. 


\section{REFERENCES}

Fama, E. and French, K. (1992). Cross Section of Expected Stock Returns, Journal of Finance, 47(2), 427-450.

Hartono, M. J. (2000). Teori Portofolio dan Analisis Investasi, $2^{\text {nd }}$ Edition, Yogyakarta: BPFE.

Husnan, S. (2005). Dasar-dasar Teori Portofolio dan Analisis Sekuritas, $4^{\text {th }}$ Edition, Yogyakarta: UPP AMP YKPN.

Jones, C. P. (2000). Investments: Analysis and Management. $7^{\text {th }}$ Edition, New York: John Wileys \& Sons.

Rosenberg, B., Kenneth R., and Lanstein, R. (1985). Persuasive Evidence of Market Inefficiency, Journal of Portfolio Management, 11(9), 1-17.

Sarwono, J. (2007). Analisis Jalur untuk Riset Bisnis dengan SPSS, $1^{\text {stEdition, Yogyakarta: }}$ ANDI.

Sharma, S. (2011). Determinants of Equity Share Price in India, Journal of Arts, Science \& Commerce, 2(4), pp. 51-60.
Tandelilin, E. (2001). Analisis Investasi dan Manajemen Portofolio, $1^{\text {st }}$ Edition, Yogyakarta: BPFE.

Utama, S. and Anton Y. B. S. (1998). Kaitan antara Rasio Price/Book Value dan Imbal Hasil Saham pada Bursa Efek Jakarta, Jurnal Riset Akuntansi Indonesia, 1(1), 27140.

Vaidyanathan, R. and Sudheer C. (1997). Stock Returns and Price to Book Value Ratio, The Icfai Journal of Applied Finance, 3(2), 45-53.

Wardjono. (2010). Analisis Faktor-faktor yang Mempengaruhi Price to Book Value dan Implikasinya pada Return Saham pada Perusahaan Manufaktur yang terdaftar di BEI, Dinamika Keuangan dan Perbankan, 2(1), 83-96.

Wilcox, J. W. (1984). The P/B-ROE Valuation Model, Financial Analysis Journal, 2, 58-66.

Wirawati, Ni G. T. (2008). Pengaruh Faktor Fundamental Perusahaan terhadap Price to book Value dalam Penilaian Saham di Bursa Efek Jakarta dalam Kondisi Krisis Moneter, Buletin Studi Ekonomi, 13(1), 92-102. 